\title{
Review on The Teaching of Building Materials in Higher Vocational Colleges Based on the "Three Educations" Reformation
}

\author{
Jing Sun* \\ Chongqing Energy College, Chongqing 402260, China \\ *Corresponding author: Jing Sun, 757809546@qq.com
}

Copyright: () 2022 Author(s). This is an open-access article distributed under the terms of the Creative Commons Attribution License (CC BY 4.0), permitting distribution and reproduction in any medium, provided the original work is cited.

\begin{abstract}
Building materials is not only a basic course content of architectural specialization, but also a practical course content taught in higher vocational institutions. It has a large number of knowledge points, a large number of principled and operational contents, and weak logic, all of which have an impact on the teaching effect. It is necessary to strengthen research on higher vocational building materials curriculum against the background of "three educations" reformation, as well as explore curriculum teaching reform strategy in conjunction with the current situation of higher vocational building materials curriculum teaching, in order to cultivate talents of high quality and professional ability.
\end{abstract}

Keywords: "Three educations" reformation; Construction materials; Teaching status; Reformation strategy

Online publication: January 18, 2022

\section{Introduction}

Modern higher vocational education emphasizes both theoretical and practical elements of training students to transfer front-line technical employees with high quality, high attainment, and high technology to architectural, service, and management positions in society. The basic course content of architecture teaching is the building materials course, which requires students to master the characters, performances, and so on expertly, as well as have good building materials detection ability, in order to lay the foundation for the construction industry's healthy development. However, there are still numerous flaws in the existing state of building materials education at higher vocational institutions. In conjunction with the reform requirements of "three educations," it is required to reform teaching and increase the teaching efficiency of construction materials.

\section{Analysis on teaching problems of building materials in high vocational education}

\subsection{The ignorance of the construction of the various teaching teacher's team}

The practice of building materials course in higher vocational colleges is relatively high. In the teaching development, teachers should not only pay attention to the explanation of theoretical teaching content, but also strengthen the improvement of practical teaching technology. Therefore, teachers must have strong theoretical and practical teaching ability to meet the requirements of modern teaching ${ }^{[1]}$. However, from the construction of teachers in modern building materials course, most teachers do not have the ability of various teaching. Although teachers have high academic qualifications and rich theoretical knowledge, their practical ability is generally weak, which limits the development of teaching work ${ }^{[2]}$. 


\subsection{The backwardness of teaching methods}

In the teaching of building materials in higher vocational colleges, from the development of teaching theory and teaching practice, the teaching methods are still relatively backward. In terms of theoretical teaching methods, traditional teaching methods are still adopted. Teachers explain the contents of teaching materials directly, and students listen or take notes passively, so the teaching efficiency is relatively low ${ }^{[3]}$. From the perspective of practical teaching, it is difficult for students to have a deep understanding of the practical teaching content, which is not conducive to the improvement of students' practical ability.

\subsection{The obsolescence of the textbook content}

Teaching materials are the carrier of teaching work, and the content of teaching materials directly affect the quality of teaching work. However, from the perspective of building materials teaching, the updating speed of teaching materials is relatively slow, which cannot meet the development requirements of the current construction market ${ }^{[4]}$. Building materials are regularly updated as science and technology progresses, their performance improves, and the construction method becomes more convenient. If the school does not pay attention to the production of school-based textbooks, instructional work will definitely be limited.

\section{The teaching strategy of building materials in higher vocational colleges under the background of reform of "three educations"}

\subsection{Strengthen the construction of teachers}

Teachers' teaching ideas and teaching abilities will have an important impact on teaching work. According to the teaching requirements of building materials course in higher vocational colleges, it is necessary to emphasize the cultivation of double qualified teachers. Combined with the singleness of the current structure of teachers in higher vocational colleges, we should actively build various teaching methods "teacher base" in teacher training, make full use of the existing teacher talent resources of the school, and form an optimized path for the construction of double qualified teachers in combination with the advanced technological advantages of company's ${ }^{[5]}$. Schools can send teachers to companies for a short period of time to learn about the most advanced building materials and testing procedures in use today's construction industry, and better convey these contents to the students to guarantee that practical teaching is efficient. Simultaneously, schools should enhance teachers' scientific research abilities, establish research and development teams in accordance with the needs of building materials development, and resolve the challenge of material research and development in the construction industry ${ }^{[6]}$. Meanwhile, collaboration between schools and companies can enhance teaching resources for schools.

\subsection{Emphasis on teaching reform}

In the teaching of building materials, practical teaching is particularly necessary, but the traditional practical teaching is too superficial, which is not conducive to the development of students. Therefore, the school needs to strengthen the reform of training and teaching both inside and outside the school, provide students with independent construction projects in the construction of school projects, detect construction engineering materials, and carry out all links from material sampling, instrument operation to data recording and judgment in accordance with the standards of construction companies ${ }^{[7]}$. They also need to establish a virtual building company model, carry out practical training and teaching, and provide hands-on opportunities for students. In addition, due to the limitations of teaching environment and equipment in school teaching, the practical teaching cannot be effectively implemented. In view of this situation, we can build an off-campus training base and an on-the-job training environment with companies. Students can directly join the work of companies for on-site training to strengthen students' cognition of practical work. In practical teaching, we need to obey the practical teaching mode of observation first, side stations second 
and practical exercises third ${ }^{[8]}$. During the observation process, students mainly go to the company for onsite learning, and the backbone personnel of the company explain the structure of various instruments, actual operation methods and essentials for students to complete the on-site observation. In the side station practice, students need to pay attention to the accumulation of experience. Students follow the master to observe the testing instruments and test methods of different building materials, and make records. Before the actual operation, the students have basically mastered the detection methods, and combined with the previous observation for actual operation, they make a record of the detection results to make a reasonable judgment on the detection results. At the same time, the practical training content is integrated into the teaching evaluation system to realize the comprehensive evaluation of teaching.

\subsection{Focusing on teaching materials reform}

Teaching material reformation cannot be done behind closed doors. Schools need to combine educational experts, construction companies and other forces to jointly create school-based teaching materials. At present, some schools still use unified teaching materials in building materials, but the content of these teaching materials is updated slowly and cannot be integrated into the latest building materials and testing methods in time ${ }^{[9]}$. Therefore, we need to pay attention to the reform of the content of teaching materials. In the reform of teaching materials, it is not simply the addition of new knowledge content, but also the formation of a perfect curriculum system with the suggestions of educational experts and construction engineers. At the same time, it is necessary to enrich the form of teaching materials, ensure the diversification of teaching materials, and integrate loose leaf handouts, work manuals, color charts and instructions of measuring instruments. While strengthening the expansion of the content of the teaching materials, due to the limited space of the paper teaching materials, two-dimensional code can be printed in the teaching materials. Students can watch some small videos of textbook theories and experiments by scanning two-dimensional code, forming a new teaching system ${ }^{[10]}$. In addition, in the compilation of new teaching materials, it is necessary to always emphasize the integration with students' posts, so that students can achieve seamless connection with their posts through the learning of teaching materials and improve the teaching effect.

\section{Conclusion}

To summarize, teaching building materials requires teachers' ability to teach, teaching techniques, and the quality of teaching materials, therefore we must focus on the integration of theory and practice in order to create a scientific teaching system. However, there are several issues and limitations in the current teaching environment. The teaching theory is not in line with practice, and the teaching techniques aren't appropriate for the job, so students won't be able to apply what they have learned after graduation. As a result, according to the criteria of the "three educations" reformation, it is required to increase the reform and improvement of teachers, teaching methods, and teaching materials, achieve the integration of theory and practice, and improve the teaching quality of building materials.

\section{Disclosure statement}

The author declares no conflict of interest.

\section{References}

[1] Hargreave M, Ge L, She L, Xiong Q, 2020, Application of Blending Learning to the Integration of Theory and Practice in Building Materials and Testing. Technology Wind, (10): 80.

[2] Ge L, Xiong Q, Qi M, et al., 2020, Course Design of Building Materials and Testing Theory and 
Practice Based on the Integration of "Course and Post Certificate Competition." Modern Vocational Education, (1): 94-95.

[3] Cai J, 2017, Design and Development of Project Teaching of "Building Materials Testing and Selection" Based on Work Process. Building Technique Development, 44(21): 1-3.

[4] Huang L, Xu S, Shen J, 2021, Teaching Status and Reform of "Building Materials and Testing" Experimental Course in Higher Vocational Colleges. Journal of Hubei Open University, 34(5): 153 $155,158$.

[5] Yang B, 2020, Discussion on Current Situation and Reform of Building Material Testing Course in Higher Vocational Colleges. Sichuan Cement, (2): 339.

[6] Luo D, 2018, Research on Teaching Reform of Building Materials and Testing Course in Higher Vocational Colleges. Sichuan Cement, (10): 326.

[7] Yang J, 2016, Research on Practical Teaching Reform of Building Materials and Testing Course. The Journal Quality of Goods, (9): 363.

[8] Xia L, Li Y, 2019, Reform and Practice of Integration Teaching of Building Materials and Testing. China Standardization, (14):65-66.

[9] Xiao C, 2021, How to Improve the Effectiveness of Building Materials and Testing Experimental Teaching. Science \& Technology Vision, (14): 103-104.

[10] Xu Y, Niu J, 2020, Teaching Reform in Higher Vocational Colleges from the Perspective of "Building Materials and Testing" Course. Journal of Huzhou Vocational and Technological College, 18(2): 44$46,51$. 